\title{
FORMAÇÃO E CRíTICA FILOSÓFICO-TEOLÓGICA NOS ESCRITOS DE TÜBINGEN
}

\section{Marcus Vinicius de Souza Nunes *}

Resumo: As pesquisas daqueles que se interessam pela filosofia e pela literatura do Idealismo alemão acabam, vez por outra, encontrando a questão da Bildung. O nosso intento é reconhecer os termos ligados a essa discussão na filosofia de Hegel, em especial aqui, fazendo a leitura daquele que é considerado o seu primeiro fragmento de reflexão filosófica.

Palavras-chave: Bildung, razão; sensibilidade; religião; moral.

Resumen: Las pesquisas de aquellos que se interesan por la filosofía del idealismo Alemán se encuentran a veces con la cuestión a respecto de la Bildung. Nuestra intención es reconocer los términos que estén ligados a esa discusión en la filosofía de Hegel, aquí de manera especial haciendo la lectura que aquel que es considerado su primer fragmento de reflexión filosófica.

Palabras claves: Bildung; razón; sensibilidad; religión; moral.

O presente escrito não se propõe a fazer algum aporte interpretativo diverso à obra hegeliana da juventude, mas apenas a servir-se como roteiro de leitura daquele que é con-

\footnotetext{
* Mestrando em Educação pela Universidade
Federal de Santa Catarina. E-mail: mvini-

* Mestrando em Educação pela Universidade
Federal de Santa Catarina. E-mail: mvinicius.snunes@gmail.com
}

siderado o primeiro texto da juventude de Hegel, escrito ainda em Tübingen, quando cursava o seminário de teologia, texto esse chamado "Religião Popular e Cristianismo" ( Volksreligion und Christentum), parte de um conjunto maior de textos conhecidos como Escritos Teológicos da Juventude, título dado por seu compilador, Herman Nohl, à data de sua publicação, em 1907.

Não obstante o caráter meramente gramatical de nossa leitura, limitada a identificar sentenças que caracterizam os temas fundamentais do texto hegeliano, encontramos um problema, aliás, um problema que nos propomos desde o início: a questão da formação (Bildung). Desde o início de nossa leitura mantivemos em vista a intenção de reconhecer no escrito analisado determinações filosóficas que nos apontassem o conceito de formação no Idealismo alemão. A nossa dificuldade foi dupla: primeiro, que o texto mesmo não gira em torno especificamente da questão por NUNES, Marcus Vinicius de Souza. Formação e crítica filosófico-teológica nos escritos de Tübingen. Revista Sul-Americana de Filosofia e Educação. Número 22: maiout/2014, p. 129-153. 
nós perseguida; segundo, algo que deve ser apresentado ainda que insuficientemente, subjaz toda a intrincada discussão de Hegel com a Aufklärung, com a teologia de seu tempo (sem dúvida luterana, mas também com a doutrina católica escolástica), com o debate filosófico sobre a moralidade, a eticidade e a legalidade, que apesar de não terem ainda ao tempo da escritura de Volksreligion und Christentum (doravante VCh) o sentido que veio a ter na Fenomenologia do Espírito, já aparecem vinculados ao sistema kantiano (positiva ou negativamente).

Não podemos resumir, entretanto, a discussão que se faz entre a perspectiva da Bildung e a religião como uma análise extrínseca. O que acontece é que não apenas encontramos indicações sobre a questão da formação a partir de textos que versam sobre teologia, mas a formação é tomada teologicamente nesses textos de Hegel que vamos analisar, ao mesmo tempo que religião e teologia são tomadas formativamente. A religião de um povo (Volksreligion, religião popular) é a forma que a compreensão que esse povo alcança a respeito de si mesmo assume.
Sair da crítica da Aufklärung e da teologia para um conceito de formação não é uma saída em sentido estrito. Estes são momentos da mesma determinação histórica, no caso, da modernidade europeia que chega a um ponto do seu pensamento que pode tomar a religiáo criticamente. Por outro lado, Hegel tenta recuperar a potência crítica da religião contra a modernidade que separa as diversas esferas da vida em compartimentos cindidos. O ideal político grego e o ideal comunitário do Cristianismo primitivo, reconstruído e reinterpretado filosoficamente, são o ponto de partida dessa crítica global, que não se resumindo à crítica negativa da Aufklärung, pretende estabelecer seguras bases para pensarmos concretamente a autodeterminação de um povo em sua liberdade como um processo formativo que poderíamos levar à cabo.

O tema da Bildung pode parecer não explícito em algumas partes do nosso trabalho. Mas, se devemos tomar a formação em Hegel hegelianamente, devemos realizar uma análise o mais rigorosa possível dos elementos teológicos e filosóficos que 
presente no texto hegeliano nos permitem a sua compreensão.

Sem mais delongas damos início à nossa análise do texto, esperando mais que as questóes se tornem claras do que as respostas imediatamente prováveis.

Religiáo Popular e Cristianismo: a filosofia $e$ a crítica teológica como resposta aos problemas da modernidade

Já na primeira frase dos textos de Tübingen pesa-nos uma sentença: "A religião é uma das questões mais importantes de nossa vida" (NOHL, 1907, p. 3). Hegel, ainda no espírito da Aufklärung, atribui à religião uma importância que é, em um primeiro momento, de ordem social, de constituição social: Desde crianças aprendemos a balbuciar palavras a uma "divindade desconhecida" (NOHL, 1907, p. 3). Sem dúvida que ao falar de uma divindade desconhecida somos aqui levados em direção ao Cristianismo. Tanto a teologia protestante, quanto o escolasticismo católico, quanto os textos paulinos nos são invocados. A divindade desconhecida, o deus pessoal do profetismo hebraico sob as figuras do entendimento, sob o conceito indeterminado da teologia. Sem dúvida que quando Hegel fala da importância da Religião não tem em vista apenas o Cristianismo. Mais, poderíamos dizer que o está em vista em Tübingen é o trabalho crítico negativo do Cristianismo institucional, teologizado e abstrato, que aparta o homem da vida da sua comunidade, em oposição à religião grega em que o deus não é o totalmente outro, mas a representação para a fantasia da subjetividade. A filosofia posterior de Hegel falará em exteriorização do espírito na forma da subjetividade. Se ainda não temos aqui uma exteriorização apresentada na ideia, já há antecipação do pensamento de um espírito que se põe a si mesmo, o da "bela totalidade grega", como uma totalidade esteticamente mais elevada que o puritanismo moral desenraizado do protestantismo.

É preciso manter a calma frente às aparentes e reais ambiguidades do texto. O tema não é pacífico para Hegel, inclusive no que a nós parece como oposições sem sentido. Em oposição à teologia protestante de seu tempo, que era a culminação da vida subjetiva cindida, Hegel tenta opor a vida grega da totalidade ética: um Número 22: maio - outubro/2014 
povo para o qual a vida política $e$ a vida religiosa, a interioridade e a atividade pública, formavam uma só totalidade. Ainda que vivendo a "nostalgia da Grécia" Hegel não cansa de exaltar a unicidade do evento Cristianismo. O que lhe é oposto à vida grega não é a radicalidade do conteúdo do Cristianismo, mas sim a figura institucional, da qual é um ferrenho crítico.

Em Hegel converge o subjetivismo de Lutero, que ressalta a relação direta e imediata do homem com Deus desde a fé (à custa da objetividade eclesiástica, da estrutura sacramental e institucional, e da mediação hierárquica) com o misticismo individualista que tende à fusão entre Deus e o homem e a importância calvinista da comunidade como realização do reino de Deus na terra. Pode-se afirmar de Hegel, muito mais que de que Kant, que é o filósofo por excelência do protestantismo. (ESTRADA, 2003, p.143).

É importante deixar claro já aqui que a religião que está em questão fundamentalmente para Hegel é o Cristianismo, e mais precisamente ainda o Protestantismo alemão, enquanto é a religião que em seu conteúdo a vida do espírito e a modernidade coincidem. Nesta religião é que o filósofo tenta reconhecer aquele móbil da liberdade, aquelas condições da subjetividade, indispensáveis para a modernidade. Desde cedo advertiu para simples oposição entre fé e razão que a Aufklärung levava a cabo, problema ao qual Hegel ainda dedicaria um texto de sua juventude intitulado Fé e Saber.

Mas, ao lado desse entendimento que vê apenas finitude em todos os lugares da verdade do ser, a religião, como sentimento - o amor eternamente pleno de anelo - tem o seu lado sublime. (HEGEL, 2009, p. 23).

Mais que a oposição, está em questão o elemento de subjetividade e liberdade que são o conteúdo da religião e a realização deste conteúdo por meio da vida política. Isso leva, inevitavelmente, a uma profunda análise da religião e compreensão dos seus processos.

Assim, o horizonte da discussão não se abre apenas sobre uma história comparada das religiões, ou de uma lição histórica, proveniente de uma história moral. Hegel não se pergunta num gesto inocente o que poderia a humanidade aprender dos gregos (TAMINIAUX, 1967, p. 5). A colocação da oposição tem como finalidade pôr em questão a própria 
noção de razão, fazendo a maior conquista da modernidade passar sob o crivo da reflexão infinita.

Já no Stift de Tübingen se mostra insuficiente para Hegel o conceito idealista e subjetivo de razão. Tanto por isso a insistência no conceito de subjetividade como exterioridade, isto é, o surgir da subjetividade no seio de um povo. A insistência no papel da fantasia presta-se também a isso. É pela livre atividade da fantasia que um povo se representa subjetivamente. A religião da beleza, a religião grega, é aquela em que a subjetividade é representada na sua beleza livre, não no terror da interioridade cristã, onde as batalhas são travadas num deserto egoístico e onde a comunidade se dissolve justamente porque apela à individualidade abstrata, não medida nas belas imagens.

Et c'est pourquoi Hegel l'associe [a razão] indissolublement à la fantaisie (Phantasie), pouvoir d'invention non au sens de construction artificielle e arbitraire mais de révélation, et au sentiment, qu'il décrit comme um acquiesciment à ce qui est et dont il souligne à maintes reprises ce qu'on pourrait apeller l'essence panique, en ce sens que dans le sentimento, c'est la totalité de l'étant qui se recueille. (TAMINIAUX, 1967, p. 7).
Esta religião, o Cristianismo mediado pela compreensão histórica da teologia escolástica, e em último momento, pela teologia kantiana do Stift de Tübingen, é tal que não nos fala à razão nem à fantasia, isto é, à satisfação dos impulsos sensiveis. É antes uma religião que tão somente fala memória, um falar que para $\mathrm{He}$ gel é um dos maiores problemas da constituição da religião cristã, pois que transforma a possibilidade de uma religião livre e libertadora de sentidos, mas que ao mesmo tempo pudesse fornecer um móbil tal a princípios mais altos, os da razão, em um mero ofício de uma casta especial, que dedica-se a uma teorização vã.

A constituição dessa casta específica para o culto vem ao encontro de um povo que dedicando boa parte de sua vida ao culto de seu deus, não por isso toma a iniciativa de sua autodeterminação religiosa, o que significaria um caminhar decidido no sentido da autonomia.

Mas, o estabelecimento de um grupo especial de intérpretes da fé, os teólogos, não invalida, como muito difundiu-se na Aufklärung, e especialmente no movimento francês, a religião mesma. Ao contrário, para Número 22: maio - outubro/2014 
Hegel a doutrina sobre Deus é uma tentativa de satisfazer a um certo sentimento moral (moralische Empfindung) de dever, específico à natureza do homem (Die menschliche Natur) (NOHL, 1907, p. 3). Não se pode correr o risco de compreender a religiáo como um sistema fechado de objetividades históricas sem relação com a vida subjetiva de uma comunidade.

No conceito de religião está implícito que não é simplesmente uma ciência sobre Deus [Wissenchaft von Gottes], sobre seus atributos, sobre a nossa relação com ele e do mundo com ele, sobre a duração da nossa lama - o que em cada caso poderia ser apreendido tão somente com a razão ou nos ser conhecido por uma outra via; está implícito que o conhecimento da religião não é apenas histórico ou racional, mas interessa o coração $e$ tem influência em nossos sentimentos e na determinação de nossa vontade. (NOHL, 1907 p. 5)

Entre vários momentos importantes desta passagem, não podemos deixar de ressaltar aqui três: primeiramente, Hegel diferencia o seu esforço intelectual e a religião mesma de uma teologia. A sua obra madura, ainda que se aproxime muito de uma teódicia ao tentar compreender as categorias com as quais Deus pensaria a si mesmo antes da criação do mundo, como propõe a ciência da lógica, não pode ser resumida a uma teodiceia. Podemos afirmar que $\mathrm{He}$ gel faz uma espécie de filosofia teológica, onde a filosofia vai encontrar seu conteúdo mais próprio na religião, realizando-o na forma mais pura que é o próprio saber. Isso, entretanto, implica um trabalho crítico de livrar-se dos preconceitos da teologia do entendimento, que é incapaz de perceber as oposições da vida concreta $e$ as conciliações o pensamento em toda sua profundidade.

O mais importante para Hegel, $e$ aqui ele dá sua contribuição à "querela do Esclarecimento", é que a religião não é apenas ciência sobre Deus (Wissenschaft von Gott); é mais que um conhecimento histórico; "interessa ao coração e tem influência na determinação da nossa vontade (Bestimmung unseres Willens)"(NOHL, 1907 , p. 5), influencia nossos sentimentos (Empfindungen). Dessa influência advêm dois motivos da força da religião: representamos como lei divina, e, portanto com mais força, uma lei que é para nós; e também a representação da sublimidade (ErhaNúmero 22: maio - outubro/2014 
benheit) de Deus nos enche de sentimentos de humildade (Demut) e gratidão (Dankbarkeit).

Em segundo lugar, a diferença com a filosofia de Kant já fica clara aqui. Hegel afasta-se de Kant quando diz que os temas relativos aos atributos de Deus, ou à imortalidade da alma, podem ser conhecidos pela razão. Isto é um flagrante contraste com a filosofia crítica e uma pequena amostra de que já no início de sua vida filosófica, ao mesmo tempo em que era receptivo a muitas categorias do pensamento kantiano, mostrava-se discordante em relação a muitas de suas conclusões;

Em terceiro lugar, e mais importante para o nosso intento aqui, Hegel vê na religião um modo de satisfação dos impulsos da sensibilidade (Sinnlichkeit) e de determinação da nossa vontade. Assim, a religião satisfaria a necessidade de móbiles da ação moral, na esteira da terceira Crítica.

Satisfazer aqui não é, entretanto, fornecer heteronimamente conteúdos morais, mas sim que a religião é um móbil que "coloca a vida humana em movimento" (NOHL, 1907, p.4). $\mathrm{O}$ pôr em movimento da vida exige que a vida mesma seja entendida em sua integralidade. Como, pois, pode a moral colocar a vida em movimento? Por mais que a moralidade deva nos fornecer um princípio tal que nos coloque acima da mera sensibilidade, ao mesmo tempo tem ela de dar conta dos sentidos, da vida sensível. E como faria isto?

Pelo apelo à fantasia. Não uma fantasia que proponha um mundo onde haveria apenas homens sem culpas e sábios, o que não passa de uma quimera. Mas sim que compreende a sensibilidade (Sinn, Sinnlichkeit), como fundamental elemento da ação humana. Para tal, um trabalho de formação ensina o homem racional, e mesmo educa os seus sentidos, para distinguir o movente da vontade (Bestimmunsgrund des Willens): se é a inteligência-sensatez (Klugheit), uma espécie de perspicácia filisteia em que predomina o mero cálculo de benefícios e prejuízos, ou uma verdadeira moralidade, livre, autodeterminada, conforme o espírito de um determinado povo.

Encontramos uma dificuldade do texto hegeliano jovem, principalmente quando tomado em relação a sua obra posterior: a diferença entre Número 22: maio - outubro/2014 
moralidade (Moralität) e eticidade (Sittlichkeit) ainda não tem a mesma concreção que tem na sua posterior filosofia (Fenomenologia do Espírito, Enciclopédia, Filosofia do Direito, ou mesmo no Sistema da Eticidade), apesar de já figurar uma diferença entre a moralidade e a mera legalidade, possivelmente herdada do sistema kantiano, e a "vida ética de um povo", a qual a moralidade deve concordar. Entretanto, fica claro já que essa totalidade ética coincide, em parte, com a concepção hegeliana da vida na pólis grega.

Pensar a relação entra a moralidade e os impulsos sensiveis exigenos pensar um problema que está no cerne da religião, especialmente cristã, a eudaimonia: o fim supremo da vida, como impulso à felicidade, tomado como bem alcançável pelo cálculo é externamente indistinguível da lei da razão determinando a nossa ação. Num sistema moral, quando o princípio de ação mais se afasta da sensibilidade, mais esta perde valor na vida humana. Um sistema que queira dar conta da moralidade tem de dar conta também da sensibilidade, das influências (dependência) externas na ação do homem e dos mo- vimentos internos de sua natureza dos instintos cegos (blinden Instinkt). A natureza humana é impregnada da ideia da razão. Como a luz, não sendo uma substância, invade um ambiente $e$ permite que tudo seja visto sem ela ser propriamente vista, assim a razão penetra todo o homem e dá a ele a possibilidade de se mostrar por inteiro.

As tarefas primordiais do pensamento e da sensibilidade eram vistas como a superação de profundas oposições que haviam sido necessárias mas deviam agora ser vencidas.(TAYLOR, 2005, .p. 20)

O Stift de Tübingen, tomado pela filosofia kantiana, especialmente pela leitura da Crítica da Razão Prática (BECKENKAMP, 2009), é para nós o exemplo claro que nos permite perceber de que modo as imbricações entre a filosofia e a teologia a partir de um racionalismo que, apesar de romper, ainda muito deve à Escolástica, serviu de forma ordinária à submissão do conceito de religião apenas ao seu fim prático. Se a tradição escolástica faz da religião uma ciência sobre Deus, o modo de compreender racional que inclusive chega a excluir o dado revelado de toda sua estrutura apelado a ele apenas ao fim do siste- 
ma, o criticismo kantiano acaba por fazer um uso, em certa instância, apenas negativo da existência de Deus. A possibilidade de sua existência como uma necessidade da razão $e$ a impossibilidade de derivar um argumento real da sua existência efetiva a partir da necessidade prática transforma o Deus teísta em um deus deísta, um deus que se serve a resolver as necessidades do sistema moral. Assim, como o próprio conceito de Deus esvaziado, também a religião cede cada vez mais espaço. Em Kant, uma religião adequada aos limites da blosse Vernunft é uma religião que não extrapolando suas afirmações dogmáticas, apenas dá aquele fundamento último para a ação moral, torna-se um móbil adjacente para a ação.

Apesar de Hegel não negar esse caráter movente da religião $e$, ao contrário, fazer do culto grego um culto que pelo apelo à fantasia transforma a vida do homem numa totalidade ética integrada, por causa dessa compreensão da vida de um povo como uma totalidade ética é que $\mathrm{He}$ gel dá um passo a diante da compreensão kantiana. A religião é a manifestação no elemento puro daquilo que há de mais íntimo na vida de um povo. Ela é a exteriorização da vida espiritual de um povo no elemento do espírito. Não a contraposição, insolúvel enquanto mantida no seu aspecto negativo, entre uma res extensa e uma res cogitans, mas a manifestação daquela integridade primeira da vida do homem que se vê cindida na modernidade.

A religião, não como ciência (Teologia), mas como parte viva $e$ integrante da vida ética de um povo funciona como um impulso "contra o poder dos impulsos sensíveis" (NOHL,1907, p. 5). Isto não significa a negação pura dos impulsos sensíveis, mas a sua transformação no interior da vida da comunidade para que o próprio homem se realize na sua liberdade. A sua conformidade com a vida ética do povo exige que em um povo de homens sensíveis (como eram os gregos) a religião seja também sensível: a religião perde em dignidade, mas ganha em fantasia. A religião mais racional não só perde em sensibilidade como impede a representação da imagem (BilderVorstellung) e até mesmo proíbe falar sobre o assunto. E aqui colocamo-nos uma questão, possivelmente, que ficará sem resposta ao longo deste traba- 
lho, mas que é de importância não só para a leitura dos "Escritos Teológicos", como para a compreensão de uma certa "filosofia da imagem", da figuração de mundo: seria o catolicismo o espaço da sensibilidade para Hegel? De fato um Hegel maduro, do qual se pode dizer que seu sistema seja católico (um sistema de figuras que se superam umas na morte de outras) termina este mesmo sistema de forma caracteristicamente luterana: a reconciliação do Espírito consigo mesmo elimina as representações. Não há imagens no Absoluto.

Mas, o que de fato caracteriza uma religião popular? O seu caráter público e o caráter fundamental de apelo à fantasia que moldam $e$ formam os sentimentos que podem influenciar o modo do nosso agir. Um espírito com força juvenil pouco pode sentir os efeitos das ideias religiosas, elaboradas, sutis, que falam à memória, mas não à fantasia. Um povo juvenil, como o trágico, se deixa mais influenciar pelas belas imagens do terror de Édipo em Colona do que pelas sutis argumentações teológicas sobre o prêmio ou castigo eternos. "O gênio jovem de um povo" (NOHL, 1907, p.6) não se deixa ficar sob o jugo de algemas. Ao contrário. A força juvenil afirma sua própria força, o modo de ser jovem é a sua própria juventude. O Gênio envelhecido, ao seu turno, é mais afeito às convenções, ao "seine Feste sind Geschwät$z e$. (NOHL, 1907, p.6).

\section{A subjetividade $e$ a objetividade da religião}

$\mathrm{O}$ que Hegel chama religião objetiva no período de Tübingen, em claro contraste conceitual com a Religião da Enciclopédia, deixa-se guiar pelo mote que rege a teologia, especialmente tomista, "fides quae creditur". A Fé como objetividade é aqui não o lançar-se no abismo do saber para o seu autoconhecer-se, mas o silêncio interminável da subjetividade frente ao alargamento sem fim da doutrina. A interiorização do saber que se exterioriza na Religião não tem espaço quando a doutrina se erige contra o pensamento especulativo. Se mencionamos a filosofia tomista, não paramos nela. A teologia protestante, especialmente a influenciada pelo kantismo quando Hegel ainda era um seminarista, também se lançou no 
absurdo da não cognoscibilidade especulativa.

A necessidade da autoconservação da religião institucionalizada na Igreja e na Teologia, não mediada pelo pensamento especulativo, se fecha à crítica. Crítica que não é mera abstração de um conceito sem vida, mas que se enraíza na vida da comunidade e, de forma muito pertinente, na vida de cada homem.

A Religião quando subsumida na mera doutrina não toca o coração do homem, nem fala por belas imagens à sua fantasia, tampouco dá espaço para a reafirmação da força de um povo, nem permite que os homens sejam formados para o uso livre de seus sentidos. Destina-se somente à memória e ao intelecto (Gedächtnis und Verstand). Procurar, reelaborar, conservar e crer são seus modos mais eminentes de autopreservação, pelo que Hegel diz que é constituída por um "capital morto (totes Kapital", que também constitui o seu âmbito referente à prática (NOHL, 1907, p. 7). Por tal, pode ser sistematizada, exposta num livro: é mera doutrina, discurso.

A religião subjetiva, por não ter o pesado fardo da tarefa da auto- preservação sistemática da objetiva, $e$ por falar ao homem na sua própria subjetividade, pode ser o espaço da efetivação da liberdade. Refere-se "somente a sentimentos e ações (nur in Empfindungen und handlungen)" (NOHL, 1907, p. 7) Por tal, o homem religioso, e para Hegel aqui significa religioso o mesmo que o homem integrado na vida ética de seu povo, moralmente, esteticamente, não é aquele que detém vasta cultura religiosa, "mas vê Deus em sua natureza" (NOHL, 1907, p. 7), atenta para suas próprias ações, vê Deus no destino dos homens.

A percepção da vida humana como manifestação da vida divina parece-nos apoiar-se na compreensão de que a perfeita autonomia não exclui a perfeita teonomia, tal como aparecerá no pensamento enciclopédico, onde a realização da liberdade na autonomia é a realização da Ideia, a realização do pensamento de Deus. Isto significa que a realização da liberdade do homem já é uma realização da liberdade da vida, uma vontade de autocomunicação e manifestação. Claro, Hegel não poderá ater-se a esta vontade de manifestação como propõe certa interpretação da teologia Número 22: maio - outubro/2014 
cristã. Em luta contra uma teologia de postulados, Hegel afirmará a igualdade da manifestação e do manifestado, excluindo a diferença fundamental que há entre o humano $e$ o divino. Em outras palavras, no pensamento Hegel adiantará a parousía.

Como teísta, ele quer ver o mundo como propositado, como existindo para cumprir determinado programa, as exigências de corporificação do Geist. Mas, como os naturalistas, ele não pode admitir um Deus que pudesse projetar este mundo a partir de fora, que pudesse existir antes $e$ independentemente do mundo. Sua ideia é, portanto, a ideia de um Deus que cria eternamente as condições de sua própria existência. (TAYLOR, 2005, p. 56).

Isto, já nos Escritos Teológicos,

não é uma negação pura do Cristianismo, mas a sua realização no conceito. Se em VCh a automanifestação de Deus propugnada pelo Cristianismo não é ainda o fator determinante de seu pensamento, Hegel entrevê essa necessidade na manifestação da subjetividade integral no culto grego. Os gregos anunciam na imediatez da sua vida sentimental e política aquilo que deve ser a sociedade reconciliada; os cristãos efetivam essa reconciliação pelo advento da divindade, ain- da que seja na consciência da infelicidade da situação presente. Ora, apenas tal pensamento pode fazer da História o altar definitivo, onde a própria divindade se oferece em sacrifício; onde o destino dos homens é a vítima que apresenta a reconciliação.

Uma religião que, historicamente, toma para si a tarefa de apresentar como a História mesma caminha para a reconciliação, não pode se resumir a predicados abstratos do entendimento. A sensibilidade deve ser integrada na religião, assim como a vida moral e política. Por isso o modelo grego é tão atraente: a capacidade de compreender o todo religiosamente e a religião a partir do todo.

Aqui, para Hegel, torna-se necessária a seguinte questão: até que ponto o ânimo de um homem, as suas ações morais, os seus sentimentos, se deixam mover por móbeis fundados em sentimentos religiosos? Esta pergunta caminha por sua vez em um sentido ainda mais específico. É importante determinar quais sentimentos específicos mais impressionam o homem, ou melhor, quais são as representações que causam melhor efeito. 
As representações religiosas de uma religião popular têm sua marca característica de serem representações estéticas. É pela beleza e serenidade das imagens apresentadas no terror da tragédia, na força jovem do mundo homérico, no culto público dos atenienses, e nas libações domésticas aos antepassados, que estão o impulso para o uso livre dos sentidos, ao mesmo tempo em que para uma moral livre. Perguntamo-nos, também direcionando esta questão ao texto hegeliano: tais representações estéticas também têm eficácia formativa no âmbito educacional? De que forma a educação, enquanto parte de um processo formativo transobjetivo e transubjetivo que é a vida de um povo, poderia tornar-se parte efetiva da formação espiritual, moral e estética, por meio das representações estéticas, semelhantes à da religião popular? Perguntamo-nos também do cristianismo enquanto substrato dessa formação: é um princípio atuante ou é apenas a ribalta do espetáculo? Parece-nos interessante notar: Hegel nos apresenta os sentimentos, morais ou não, no nível da representação: o sentimento singular é representação em um povo? O processo formativo de um povo é também a educação dos sentidos, do coração, da consciência: o coração duro é ouvido mouco, não ouve o interior, a consciência. (NOHL, 1907 p. 8).

"A religião popular produz $e$ nutre as grandes disposições afetivas, procedendo passo-a-passo com a liberdade" (NOHL, 1907, p.28). A religião subjetiva depende do despertar de uma disposição afetiva ${ }^{1}$ (Stimmung). Ora, Stimmung é antes uma afinação do sujeito com o objeto em que a própria duplicidade está desfeita. A interioridade não está, no sentimento religioso subjetivo, em plena harmonia com a exterioridade. Os primeiros cristãos eram reconhecidos na sua interioridade porque estavam afinados com suas ações. Stimmung é Rezeptivität, um estar pronto a receber estímulos estéticos e espirituais para o desenvolvimento da

$2 \mathrm{O}$ tradutor italiano preferiu à Stimmung a expressão "intima inclinazione". Os acostumados à questão filológica reconhecem a dificuldade da tradução do termo alemão, dada a sua amplitude semântica já na linguagem coloquial. Quanto mais filosófica se faz a compreensão do termo Stimmung, mais nuances e dificuldades surgem na sua tradução. Escolhemos a expressão "disposição afetiva" por sua conformidade à tese da reconciliação entre razão e sensibilidade proposta no texto hegeliano. Assim, a disposição que nasce na afetividade é um estar-preparado para o pensamento que reconcilia.

Número 22: maio - outubro/2014 
vida interior, desenvolvimento o qual só pode ser constatado pelo efeito da vida moral do singular na vida de seu povo.

A religião objetiva, por sua vez, não depende da formação de uma disposição, mas é ensinada: "um trabalho conjunto sobre o intelecto (Verstand), a memória (Gedächtnis) e os livres sentidos (offenen freien Sinnes)" (NOHL, 1907, p. 7). Pelo trabalho do intelecto se imprime em nossa memória e em nossos livres sentidos o peso da religião objetiva: para nós o importante está em dizer "offenen freien Sinnes", ou seja, da mesma forma que se pode educar os sentidos para envelhecer sob o peso da objetividade, também se pode educá-los para serem livres: os povos jovens $e$ fortes, em que seu culto é culto da sua própria força. As forças da alma deixam de lado esses nutrientes que a nada servem. A educação da alma, a educação espiritual, é um projeto diferente do projeto da Aufklärung. Esta propõe, com seu mundo livresco $e$ intelectualizado, uma separação ainda maior entre a condição concreta da sociedade e o modo de vida intelectual: o próprio intelectual é alguém que não apresenta o modo de vida da sua comunidade, mas se coloca abstratamente para além dela no entendimento. A educação integral dos membros de uma comunidade é também liberação de sentidos, integração da sensibilidade e sua transformação, sua elevação junto com a razão a algo mais alto que as duas, o homem nas suas múltiplas realizações.

\section{Religião e formação}

As sensações não são inimigas da moralidade. Não há, e não deve haver, um conflito real entre os interesses da sensibilidade e aqueles da moralidade e da razão. Uma educação integradora totaliza essa multiplicidade na unidade da vida do homem. Assim, certas sensações não apenas não se opõem à moralidade, como afirma a moral pietista $e$ o kantismo consonante a ela, mas têm sua origem nela. Tais sensações, pela mediação da religião e da educação, se abrem a algo que é um despertar para a vida moral (Sinn fürs Moralische), ou seja, propõem-se alcançar fins mais altos que aqueles propostos pela mera sensibilidade (Blosse Sinnlichkeit) não integrada num projeto global de realização. 
Que estes belos germes não sufoquem, que surja uma efetiva receptividade para as ideias e sentimentos morais, é uma tarefa da educação, da formação. A religião não é a primeira que pode lançar raízes no ânimo. Ela deve, antes, encontrar um terreno favorável no qual possa lançar suas raízes. (NOHL, 1907, p. 8)

As ideias e sentimentos que a religião inculca não são vinculantes prima facie. Antes que a religião possa surtir efeito na conduta moral do homem é necessário que se desenvolvam aquelas aptidões necessárias para a vida do espírito. A anterioridade pertence à educação, à formação $(E r-$ ziehung, Bildung). Esta anterioridade não é meramente cronológica, como se o menino educado fosse a preparação do homem religioso.

Espírito do povo, história, religião, grau de liberdade política de um povo, nada disso pode ser considerado separadamente, nem no que diz respeito aos múltiplos e mútuos influxos nem no que se refere à natureza particular de cada um desses elementos. (NOHL,1907, p. 28).

Há uma relação intrínseca entre a educação e a religião. As ideias de um povo, o modo como ele se compreende em sua religião são determinados como um todo pela formação que esse povo recebe. Mas, ao mesmo tempo, o tipo de formação que esse povo pode dar a si mesmo só é possivel a partir da précompreensão que estabelece de si mesmo. A religião enquanto uma educadora moral só é possível a partir de uma Erziehung anterior a ela; mas esta só é possível porque ela e a religião que dela provém $e$ na qual se enraíza, copertencem a um processo ontologicamente anterior de Bildung, de formação, na qual os elementos constituintes não evoluem separadamente mas se codeterminam.

"Tudo converge na religião subjetiva" (NOHL, 1907, p. 8). A esta altura Hegel obriga-se a fazer abstração das discussões metafísicas: metafísica, relação do homem com Deus como um objeto totalmente diferente dele, com o qual não tem nenhuma relação de determinação ontológica da qual possa se compreender como fundamentado no fundamento último, mas apenas como uma contingência indeterminada do espírito, já não é religião, mas teologia: a teologia é uma tarefa refinada do intelecto e nada diz aos sentimentos morais. Os sentimentos morais fundam-se naqueles poucos princípios fundamentais ("apresentados de maneira mais ou Número 22: maio - outubro/2014 
menos pura") das religiões $e$ que a teologia nada pode dizer.

Faculdades diferentes estão envolvidas na religião e na teologia. Na teologia estão envolvidos, como já dito, o intelecto e a memória. Já a Religião, subjetiva, é uma "tarefa do coração" (Sache des Herzens) (NOHL, 1907, p. 9). Esta tarefa é uma espera. Esperar a realização do sumo Bem. Assim, temas fundamentais da religião objetiva (e diga-se, da filosofia kantiana), aqui reaparecem, como uma dupla exigência de fé da razão prática: na existência da divindade e na imortalidade da alma.

O processo de formação mediado pela religião subjetiva é um processo de formação daquilo que Hegel chama, à altura, "consciência": "sentido interior do justo e do injusto" (NOHL, 1907, p. 9). Não importa qual advento natural possa ter causado a crença do homem num ser invisível muito superior a si, mas sim que sempre que houve religião esteve ela calcada sobre a ideia de uma relação de justiça e injustiça, sobre um sentimento moral que garante ao crente a recompensa e ao culpado o castigo. Esta relação, entretanto, não pode esgotar a manifestação inteira da reli- gião: esse é o erro da teologia calcada no entendimento, como a teologia racionalista protestante. Não apenas pela exigência moral a religião se mostra, mas ao se apresentar como moral apresenta também a sua realidade enquanto compreensão abrangente da vida.

Vale notar que a religião popular difere radicalmente da superstição. Ainda que na religião popular sejam repetidos os apelos estéticos, e que por tal esteja calcada na sensibilidade, como a superstição no sinal material, há uma diferença quanto ao móbil da ação. Na superstição, o movente (Bestimmungsgründe) da ação é mera inteligência-sensatez (Klügheit), fundada nas limitações do entendimento, que tenta manipular o descontentamento da divindade em relação à má ação.

$\mathrm{O}$ apego à sensibilidade, aos sentidos, não impede que povos sensíveis desenvolvam uma religião moral: esta religião será religião sensível - a divindade compartilha as mesmas limitações da sensibilidade humana mas no conceito de deus e de seu culto já se encontra moralidade. $\mathrm{O}$ culto presume um ordenamento superior - as ações humanas passam a se Número 22: maio - outubro/2014 
orientar por um fim maior que a mera sensibilidade.

"Simplicidade de espírito e de coração" (NOHL, 1907, p. 10): não importam aqui os frios cálculos do intelecto (kalten Verstand berstrichtert). A capacidade da vida moral e espiritual não pode, por sua própria definição, estar exclusivamente atrelada a uma única religião histórica. As religiões, em sua pluralidade, são assim a manifestação dos fundamentos do espírito, numa realidade espaçotemporal.

Por isso ocorre a "derrota do amor" (NOHL, 1907, p. 11): o intelecto fala mais alto que o coração no que se refere a ações morais. $\mathrm{O}$ que falta ao agente dotado mais de cultura religiosa do que de religião é uma consciência adquirida da experiência agente. A formação de um povo passa mais pelas ações em sua própria história que os indivíduos realizam, do que da mera cultura abstrata.

\section{Uma vida cindida}

Apesar de não procedermos aqui a uma análise precisa do problema, é-nos necessário apresentar alguns aportes no que se refere ao problema da vida cindida. A cisão entre a vida subjetiva do homem $e$ a objetividade das instituições e dos processos históricos já nos deixa entrever que há uma cisão mais profunda ainda a ser posta a claro: uma laceração ontológica do próprio homem.

A separação entre a vida concreta e mero dever-ser do moralismo abstrato só é possivel a partir de uma sutura na própria subjetividade. A própria constituição subjetiva inclui em si as suturas da vida objetiva. Vêse que é necessário um meio absoluto para reparar essa cisão, um meio que é em si finalidade para o homem, a reconciliação absoluta.

Com uma espécie de genealogia, que emprega em $V C h$, Hegel nos mostra a contribuição do Cristianismo nessa separação radical que constitui a modernidade. O sujeito moderno, preso entre a objetividade totalizadora das instituições alienadas e a subjetividade radical, sem vínculo vivo com a história. Apresentamos aqui, então, apenas alguns aportes de cisões específicas fundadas no próprio conceito de subjetividade cindida, que embora Hegel não o formule claramente em $V C h$, perpassa todo o texto. 
O Cristianismo deu margem a uma cisão entre vida e doutrina (NOHL,1907, p. 26). O homem não deveria envergonhar-se de seus sentimentos naturais frente à religião, mas a doutrina positiva excede os limites do entendimento que lhe são próprios exigindo do homem ações que são totalmente contrárias aos seus impulsos naturais. Aqui a cisão se mostra como a incapacidade do entendimento de reconciliar o sujeito não com o objeto, mas consigo mesmo. A teologia pietista, a teologia do entendimento, só é capaz de apresentar uma doutrina moral abstrata que não se adequa às capacidades naturais dos homens. Claro, este não é um mérito apenas do protestantismo. Também o catolicismo é refém de uma teologia moral desligada de uma verdadeira teologia espiritual, ou como poderíamos dizer utilizando o jargão teológico, uma teologia fundamental, que tenta fazer a religação conceitual da natureza e do espírito pressupondo essa união a partir da própria efetividade da vida espiritual.

Para Hegel a religião popular é diferente, pois é amigável com os sentimentos da vida (NOHL, 1907, p. 26). A religião deve acompanhar amigavelmente todas as ocasiões da vida de um povo, como entre os gregos, entre os quais as festas populares eram festas religiosas em honra dos deuses.

O Cristianismo ao contrário, quer educar os homens para serem "cidadãos do céu" (Bürgern des Himmels): desta forma os sentimentos naturais tornam-se estranhos ao próprio homem. Não à toa a festa máxima do Cristianismo, Paixão, não celebra os sentimentos naturais, mas provoca um temor. Os gregos, ao contrário, aproximavam-se dos altares de seus deuses com flores e vestidos de alegria. "Espírito do povo, história, religião, grau de liberdade do povo não podem ser considerados separadamente, nem no que diz respeito ao seu mútuo influxo nem no que respeita a sua natureza" (NOHL, 1907, p. 27).

São os povos antigos que melhor aprenderam a mediar seus sentimentos com os influxos da fantasia. Os gregos produziram para si imagens do mundo e nestas mesmas imagens viram refletidos, ou melhor, apresentados, os caracteres fundamentais de suas disposições de ânimo mais profundas. Ainda que o espírito de tal Número 22: maio - outubro/2014 
povo se mantenha aferrado aos cultos da natureza, pouco dotados de interioridade, consegue adornar o seu agir com as belas imagens da fantasia. Guardavam a "consciência da sua força e de sua liberdade". O "fauno do bosque" não era a religião dos gregos, mas "o amor e alegria" que eram apresentados nos ornamentos do coração e do sonho. Uma verdadeira educação da natureza (Erziehung der Natur) (NOHL, 1907 p. 29): deixar que um povo forte fique entregue às suas disposições de ânimo e que o próprio gênio do povo seja educado a preservar as disposições mais propícias à sua realização $e$ a superar as mais nocivas.

Interessante notar a expressão que Hegel faz uso: Erziehung der Natur. A pergunta que nos cabe é: o que Hegel entenderia especificamente, a esta época, por educação da natureza? O uso da expressão pode nos evocar a lembrança de Rousseau, o qual Hegel tinha lido ainda no Stift de Tübingen. Sem dúvida que se trata da natureza humana, das inclinações, desejos, impulsos, sentimentos, sensações, que podem contribuir para a liberdade ou que podem impedir o seu desenvolvimento. Mas, não será também a totalidade da natureza, os elementos vivos da terra e do céu, colocada em questão? Não é possível afirmar que a natureza seja sujeito de um processo formativo, mas isso não implica que não possa ser incluída no processo. A compreensão da totalidade que é vida, que é uma chave de leitura para o do pensamento de $\mathrm{He}$ gel nos Escritos, inclui a necessidade da conciliação da multiplicidade vivente, do existente.
A libertação da natureza é a recuperação das forças estimu- lantes da vida na natureza, as qualidades estéticas de ordem sensual que são estranhas a uma vida desperdiçada em in- termináveis desempenhos competitivos; elas sugerem as novas qualidades da liberdade. (MARCUSE, 1981, p. 64)
Não queremos, de forma alguma, apenas lançar esta afirmação de Marcuse para dentro da filosofia hegeliana. Ademais, a própria maturidade de Hegel pode contrariar a proposta de Marcuse. A Ciência da Lógica e a Enciclopédia deixam pouco espaço para natureza como espaço de liberdade. Aliás, só há natureza livre quando conservada no conceito. Entretanto, a relação intrínseca entre necessidade e liberdade no sistema 
hegeliano nos abre a porta de uma compreensão do seu sistema.

A natureza relegada a si como uma objetividade conceitual é algo próprio da metafísica do entendimento. A metafísica elevada a conceito total, sem ser dialetizada, é espaço de alienação. Assim que os problemas afetivos são hoje tratados com alopatia; os comportamentos destoantes como o padrão de normalidade imposto como regra são medicalizados; e os próprios eventos políticos podem ser vistos como consequência de nossa natural tendência ao egoísmo.

Isto não é, absolutamente, compreender a natureza em sua amplidão conceitual e objetiva. Quando dizemos "natureza", "natural", todo um escopo de conotações e denotações se abre, revelando a própria história do conceito. A natureza só é natureza como um todo enquanto é para nós. $\mathrm{Na}$ vida dos animais há predadores e presas, parceiros sexuais e intempéries; mais propriamente, talvez nem possamos dizer que haja isso, mas que há apenas o que há: o possível modo de compreensão que um animal estabelece. Mas, natureza não há de forma alguma para a própria natureza: o conceito só existe para nós. Assim, educação da nature$z a$, seja entendida como o processo em que o homem é conduzido a realizar plenamente os seus instintos $e$ dotes naturais, seja como um processo de formação do sujeito que inclui o mundo natural, só é possível afirmando a relação intrínseca do objeto com o conceito que é para nós.

\section{A cisão e a moral}

A figura que, para Hegel, constitui a oposição formal e do conteúdo em relação a uma educação da natureza é o moralista. Sejam filósofos da moral, sejam teólogos da moral, todas as suas qualificações teóricas são incapazes de abrir-se à forma $e$ ao conteúdo efetivo da razão humana.

O ofício de "moralista" tem agudas limitações, que tocam à eficácia do ensinamento moral: só àqueles que a natureza nos destinou por mais próximos podem ser afetados pelo discurso moralizante. E é pela via de escritos que se tenta moralizar no mundo cristão, isto é, pelas dissertações morais de todo o tipo. E aí está o perigo do ofício: cair na roda dos erros teóricos. A moralidade não é um efeito do trabalho teórico, mas um 
resultado dos afetos internos, das disposições.

Entre os gregos, "em seu estado republicano" (NOHL, 1907, p. $30)$, havia liberdade de fala entre os cidadãos. $\mathrm{O}$ moralista do estado grego, Sócrates, de acordo com o gênio de seu povo tinha de falar mais livremente com o seu povo, utilizando de movimentos estéticos que fossem ligados aos sentimentos do seu povo. Sócrates não usava "um tom didascálico".

Já entre os hebreus, habituados a discursos morais, no modo de seus poetas nacionais, acostumaramse a fazer discursos moralizantes em público, o que criou um tipo de moralidade mais afeita à memória que aos sentimentos e inclinações. As próprias disputas de escribas $e$ fariseus era controvérsia pública em torno do texto, costume que permaneceu no Cristianismo. Isto, de fato, colaborou para o desenvolvimento de uma exímia educação teórica, mas não para a educação dos sentimentos.

Mesmo a melhor educação não exime o homem de procurar durante toda a sua vida o aperfeiçoamento moral, assim como o mais humilde dos homens deve melhorar sempre mais a forma de seus relacionamentos com os outros homens. A vida burguesa, entretanto, tornou esse melhoramento do agir cada vez mais difícil. Na vida civil, mesmo a retidão de agir sempre se encontra em "colisão de deveres" (NOHL, 1907, p. 31). Não há na vida burguesa uma conciliação entre os imperativos morais, a lei civil e o sentimento moral. É a diversidade de relações da vida burguesa que cria a diversidade de deveres, a quase impossibilidade de unificá-los.

Essa recusa ao ofício de moralista incide diretamente sobre as conquistas da Aufklärung. A proclamação do homem como sujeito universal se baseou na compreensão de uma individualidade abstrata. O mero indivíduo, desde os textos de Tübingen não pode constituir um sujeito de direitos, não só legais como morais. Todo desenvolvimento da liberdade pressupõe a comunidade em que se desenvolvem os direitos.

Ademais, a fim de tornar nossos desejos reais no mundo da história, temos de atingir objetivos comuns, pois a única realidade auto-subsistente é uma comunidade, e qualquer formação de coisas que serão auto-subsistentes tem de ser a

Número 22: maio - outubro/2014 
formação de toda uma comunidade. É preciso que haja uma aspiração comum. (TAYLOR, 2005, p. 130)

Sem deixar de considerar a teoria comunitarista de Taylor, temos de reconhecer o acerto interpretativo que realiza. Mesmo a "educação da natureza", que envolve o controle dos impulsos cegos do instinto, uma educação que procura conciliar razão $e$ sensibilidade na vida subjetiva, pressupõe como princípio e fim uma comunidade de sujeitos que gozem a liberdade de compartilhar princípios comuns.

\section{Conclusão}

Uma pergunta constantemente repetida é: por que estudar Hegel em educação? É óbvio para todos os conhecedores do seu pensamento sistemático que não é um filósofo da educação. Apesar da publicação de seus Textos Pedagógicos, que se constituem basicamente de seus discursos de início de ano letivo e de cartas escritas a Niethammer, então responsável pelos liceus de Nuremberg, não se tem em geral muitos textos que avancem um pouco mais nessa pesquisa de Hegel como educador. Claro, pode-se também reconhecer a própria "Fenomenologia do Espírito como romance de formação", título de um artigo de Bento Itamar Borges.

Um outro modo de acercarnos da questão da relação de Hegel com o pensamento pedagógico é a sua preocupação com as questões de sua época, em especial com o Romantismo. Hegel, especialmente a partir da Enciclopédia, vai ser considerado como antirromântico. Embora não seja possível a discussão desta questão aqui neste artigo, em muito as concepções de Hegel assemelhamse com as do Romantismo, se não pela forma da discussão, inevitavelmente pelo seu conteúdo. Esta é a questão da conciliação de razão $e$ sensibilidade, ou como propõe Taylor (2005), da liberdade e da unidade expressiva.

Sem deixar de serem questões pertinentes, aliás, indeclináveis para compreender uma possível relação de Hegel com a pedagogia, não nos mostram exatamente o caminho que podemos alcançar com o seu pensamento. Ora, o processo formativo compreendido como conciliação da própria subjetividade e da comunidade nos aponta uma saída. Claro, reconhecemos todo o trabalho da críti- 
ca do século XX dos limites dessa compreensão, limites que beiram o totalitarismo político e a tibieza acadêmica, a impossibilidade de usar uma filosofia que termina em um conceito positivo que permanece na quietude de seu próprio saber servir como o método da crítica. Mas, os problemas de nossos processos formativos ainda caminham na esteira da cisão da vida subjetiva, hoje apresentada num individualismo grosseiro e radical, em que a vontade torna-se hedonismo e a biografia, mídia.

A filosofia hegeliana da juventude, em especial os textos de Tübingen que aqui abordamos, está cheia de acessos que nos permitem chegar a uma crítica mais consistente da cultura contemporânea. Não obstante a derrocada da razão esclarecida, autossuficiente, que se opunha a toda manifestação intelectual que não se resumisse ao dado empírico e ao cálculo abstrato, alguns problemas da sociedade contemporânea nos indicam que ainda estamos longe de uma visão formativa integrativa.

Ninguém é capaz de negar a grande vitória que é o Estado laico. Entretanto, a partir do pensamento, não podemos deixar que as conquis- tas da sociedade secularizada obliterem as influências da religião na formação do Ocidente. Certo que a expressão "civilização ocidental" pode sofrer a acusação de pretensões megalômanas. Mas mesmo assim nos sentimos à vontade de reconhecer um grande grupo linguístico, cultural, político, e também religioso nos quais se inserem as nossas práticas formativas.

As mais recentes inovações $e$ pedagogia, em ciências da educação e em teorias da educação devem ser encaradas na sua justa perspectiva. Constituem um avanço, ensaios de reflexão prática, mas têm deixado de lado dimensões fundamentais da vida de nossas sociedades. A forma mais premente de ensaiarmos um modo de sanar esses limites pode se indicado por essa genealogia, como dissemos, talvez equívoca, mas que nos permite aproximarmo-nos das raízes de nosso problemas.

Talvez seja indelicado exigir de uma reflexão filosófica sobre a educação que parte de pressupostos tão amplos, e talvez genéricos, que aponte soluções, respostas, modelos de prática pedagógica. Mas é impreterível que se exija dessa reflexão que aprofunde cada vez mais nos probleNúmero 22: maio - outubro/2014 
mas. A serialização do saber, a compartimentação da educação, as cisões da vida subjetiva têm se mostrado como problema na medida em que esse modelos têm se mostrado incapazes de desenvolver as capacidades políticas indispensáveis para a vida democrática. A disjunção racionalidade-sensibilidade parece, e já de acordo com Hegel, uma das razões das crise de uma sociedade que se desenvolve científica e tecnologicamente mas que fica a dever na vida democrática e política.
Reconhecer na obra de Hegel os conceitos que nos possibilitariam oferecer uma alternativa às concepções formativas e políticas atuais implica o reconhecimento da amplitude dos mesmos conceitos em sua obra $e$ em relação à discussão do seu tempo. A amplitude semântica nos obriga o conhecimento do contexto. $\mathrm{O}$ que este pequeno trabalho tentou apresentar foi justamente a reconstrução de um cenário conceitual em que, ao menos, queremos entrever uma opção para o próprio pensamento.

\section{REFERÊNCIAS}

BECKENKAMP, J. O jovem Hegel: formação de um sistema pós-kantiano. São Paulo: Edições Loyola, 2009.

BORGES, B. I. A Fenomenologia do Espírito como romance de formação; in: Veritas, v 55, n 3, set-dez 2010, pp.158-177. Porto Alegre.

ESTRADA, J. A. Deus nas tradiçóes filosóficas: Vol. II Da morte de Deus à crise do sujeito. Trad. de Maria A. Diaz; São Paulo: Paulus, 2003.

HEGEL, G. W. F. Fé e Saber. Trad. De Oliver Tolle; São Paulo: Hedra, 2009 Hegels theologische Jungedschriften; herausgegeben von Herman Nohl; Tübingen: Verlag, $1907 . \quad$ Disponível em http://www.arcliive.org/details/hegelstheologiscOOhege. $\overline{\text { Editori, } 1977 .}$

Scritti Teologici Giovanili; Trad. di N. Vaccaro e E. Mirri; Napoli: Guida

MARCUSE, H. Contra-revolução e revolta. Rio de Janeiro: Zahar, 1981.

TAMINIAUX, J. La nostalgie de la Grèce à l'aude de l'Idealisme Allemand. La Haye: Martinus Nijhoff, 1967. 
Revista Sul-Americana de Filosofia e Educação - RESAFE

TAYLOR, C. Hegel e a sociedade moderna; trad. de Luciana Pudenzi; São Paulo: Edições Loyola, 2005.

Recebido em 16/08/2013

Aprovado em 19/05/2014 